\title{
Yoga Is A Way to Handle Stress
}

\author{
Maria Kuman* \\ Holistic Research Institute, USA
}

Submission: July 24, 2018; Published: September 20, 2018

*Corresponding author: Maria Kuman, Holistic Research Institute, 1414 Barcelona Dr., Knoxville, TN 37923, USA,

Email: holisticare@mariakuman.com

\section{Abstract}

This article reveals for the first time the true origin of Yoga. Yoga and acupuncture came with Tao from the civilization before the Noah's Flood. The article also explains how stress causes muscle tension and how both Yoga and acupuncture can be equally successfully used to reduce the tension, balance the body again, and prevent the disease, which would other way result from the stress. The article finishes with the Yoga teaching how to avoid being stressed and avoid being angry because anger is very destructive- "anger is only one letter away from danger".

\section{Introduction}

'Yoga' means 'United with God'. It is a set of physical exercises, which aim to help you feel your muscles- are they tense or relaxed. Each exercise is combined with breathing exercise and alternated with relaxation. The purpose of all this is to learn to relax your muscles and mind, so that you can meditate, i.e. put your conscious (the digital computer) to sleep and let your Subconscious (the quantum computer) manifest itself [1]. The quantum computer is our gift from God and it allows contact with the Creator God [2].

Yoga has been practiced in the East for millennia. The Western world got acquainted with it through the books, visits, and teaching of practicing Yogi from India and other Eastern countries. India thinks Yoga has always been Indian and if it is practiced in China, it is because it has been transferred to China from India. The Chinese claim that Yoga originated in China. It was part of the Tao's teaching, which was accepted as official religion of China around 2500 B.C. during the reign of Chinese Greatest Emperor Huang Ti(M. Kuman, Ancient History since Noah's Flood - How Modern Science ShapesIt [3].

The Chinese claim that Tao, with the incorporated in it Yoga, stayed in China for 18 generations of Chinese Emperors. Then it was transferred to India for 18 generations of Chinese Emperors, after which it was transferred back to China. I have the proof that this is true because for many years I asked many prominent Yogi from India what the basis of their recommendations and restrictions and I got as an answer to all of them "Guru knows", which means their teacher knows, but they don't know.

I got answer to all my questions when I got acquainted with Tao. Obviously, during the transfer of Yoga from China to India, Yoga got disconnected from Tao and the basis of the Yoga's recommendations and restrictions was lost. I wrote a book on Yoga: M. Kuman, Yoga - Health Benefits, Science, and Wisdom[4], in which Yoga is re-united with Tao, and this is the only book of this kind. I started doing Yoga spontaneously as a child. In high school, when I open the first book on Yoga, I was surprised to see 'my gymnastic' in the book.

The consecutive transfer of Yoga from China to India and back enriched the ancient wisdom with features specific for each of these cultures. For example, in the Indian literature the energy vortices are called chakras (spinning wheels), while in the Chinese acupuncture books they are called energy seas, in which the energy of the acupuncture meridians flow into (See the book of the author: M. Kuman, Modern Aspects of Ancient Acupuncture [5], which is the only book that explains scientifically how acupuncture works). Thus, the chakras are spinning energy seas or spinning energy centers.

Also, the ancient Tao teaching for transformation of sexual energy into spiritual was embraced by the Indians, fringed with Indians dances, music, and rituals and offered in India under the name Tantrism. Tantrism is also a philosophy teaching that everything is waves and vibrations. The Indian Yoga is broader, which makes the Indians think that they are the primary source. The Chinese Yoga is narrower, but offers more details, like explanation through Tao of the Yoga's recommendations and restrictions.

The Chinese ancient acupuncture books speak with admiration about the wisdom of the ancients, who knew how to live in harmony with the Universe and their surroundings, how to avoid negative emotions and thoughts in order to stay happy, and therefore healthy. They knew about the body hormonal 
rhythms (circadian, monthly, and seasonal) and it was a mystery for me for many years: Who were these ancients that were so smart and had such advanced knowledge?

After a long search I found that the Tochari, descendants of Japheth, son of Noah, brought Tao (with Yoga and acupuncture as branches) to Asia. These descendants of Noah fled to Asia after a local flood of the Black Sea 7,000 years ago. Robert Ballard, who found the wrecked ship Titanic, dated this flood. This means that the wisdom and origin of Tao, Yoga, and acupuncture should be sought before Noah's Flood of 9,500 years ago (see the book of the author: M. Kuman, Ancient History Since Noah's Flood - How Modern Science Shapes It [3].

The book of M. Kuman: Ancient Wisdom and Modern Science about Health and Happiness[6] compare the wisdom of the ancients and their knowledge about hormonal rhythms with contemporary science and the agreement is spectacular. I also want to share my surprise that I found my family name Kuman as a name of a Desert (Kuman Desert) in northwest China. This was the place where the spiritual Tochari, descendants of Noah, lived. It used to be a lake with monastery around the lake. But the lake gradually dried out.

So, this place was the Spiritual Center of Middle Asia. The rooms of the monks were honeycombed into the cliffs. In one of the rooms walled up with bricks ancient manuscripts were found with Tao and Buddhist scripts written in Tocharian language, which was identified as the mother language of Sanskrit. No wander, my name 'Kuman' means 'Spiritual Man' in all ancient languages: Hebrew, Aramaic, Sumerian, Sanskrit, and Gallic.

\section{Stress and Muscle Tension}

If you are angry, you usually feel like hitting the fellow that made you angry and running. This is a reaction hit and run. Usually, you don't hit and run, you are just angry. However, all the muscles of the hands and shoulders that would be involved in the hitting would be mobilized and they would remain tense long after the stressor is gone. Chances are that the stiff muscles will cause problems of one or another kind, since neither blood, nor lymph, nor nerve circulation is proper there [4].

If you hit in a burst of anger, lead by the fear that you will be hit back, you run. Even when you don't really run because you didn't hit, you were just angry, your body is mobilized for escape reaction.All muscles that would be involved in the run will be mobilized and will remain tense long after the stressor is gone. Thus, fear is the fuel of each escape reaction and leads to tense escape muscles [4].

When somebody is verbally offending you and you don't really feel like fighting back because you feel guilty, you exhibit defense reaction. You instinctively tuck your head between your shoulders for protection. This leads to tense muscles of the neck and shoulders and they remain tense long after the stressor is gone [4].
Thus, stress leads to tense muscles regardless of which type: hit-and-run, defense, or other muscles. Permanent stress or long-term negative emotions, by impairing the blood, lymph, and nerve circulations dysfunction the involved muscles and dysfunction the genetically inherited weak organ, whose function collapses first under stress manifested as chronic disease or cancer (See the Books: M. Kuman, What Everybody Needs to Know about Chronic Pain, Chronic Diseases and Cancer[7] and M. Kuman, Stress as Killer, Stress as Healer [8].

Besides, each tense muscle fires impulses to the brain all the time. Therefore, if you want to achieve peace of mind, or give rest to your mind, learn to relax all your muscles. By exercising and then stretching and relaxing the tense muscles, you can free your brain from the unnecessary blast of impulses, which will allow you to have proper rest during the night. Relax muscles improve dramatically the quality of your sleep and rest.

\section{Stress Destroys the Body Balance}

The muscles that contract (fold) the limbs are called flexors. They are ruled by the sympathetic nervous system. In the Chinese terminology they are Yang (active) muscles. The muscles that stretch the limbs are called extensors. They are ruled by the parasympathetic nervous system. In the Chinese terminology, they are Yin (passive) muscles.

The stress of life loads the sympathetic nervous system and creates imbalance between the sympathetic and parasympathetic nervous systems, which causes pathology. Through Yoga exercises, the balance could be restored, the harm of stress avoided, and the pathology prevented. The presently used aerobics exercises are not based on knowledge of the muscles' balance and how to restore the body balance. However, the ancient Yoga and Tai Chi exercises were designed to restore the body balance.

\section{Achieving Balance through Yoga Exercises}

Yoga and Tai Chi exercises with stretching were designed to restore the balance of Yang (flexor muscles) and Yin (the extensor muscles). This brings back the balance between the sympathetic and parasympathetic nervous systems, which keeps the body healthy. Such balance could be also achieved with proper acupuncture treatment, which release the muscle tension through puncturing the tendons of the muscles with needles.

In the way acupuncture can release the muscle tension and prevent the stress-induced pathology, doing Yoga exercises on a regular basis serves the same purpose; it prevents the stressinduced diseases just as preventive acupuncture does.

\section{In Yoga Body, Mind, and Spirit Are One Whole Piece}

The ancient Chinese used to say: "Healthy body, healthy Spirit", but they also emphasized that "you need to have healthy Spirit to have healthy body". They emphasized the importance of positive thinking and positive emotions and the importance of 
avoiding negative thinking and negative emotions. The ancient Greeks and Spartans also said: "Healthy body, healthy Spirit", but they fail to emphasize the importance of the opposite - "you need to have healthy Spirit to have healthy body".

Yoga is designed not only to take care of the stress-induced tense muscles and prevent stress-induced pathology. Yoga teaches how to prevent stress. Yoga teaches that only the dumb people become angry. The smart people know that anger is only one letter away from danger, and they would do everything to prevent the anger. Anger is always preceded by irritation. Notice the irritation and stop it from growing into anger. This is what smart people do.

Only dominant positive thinking and positive emotions can bring you the inner peace, which is the key to health and longevity [9]. The oldest person who lived on Earth was the Chinese citizen Li Chang Yun, who lived to be 256 years old according to written records. When asked what made him live so long, he answered simply: "Inner peace and periodic cleansing."

\section{References}

1. M Kuman (2018) Research in Medical and Engineering Sciences 1(4).

2. M Kuman (2018) Current Trends in Complimentary and Alternative Medicine: 1(1).

3. M Kuman (2003) Ancient History since Noah's Flood- How Modern Science Shapes It, Health and Happiness Books.

4. M Kuman (1999) Yoga- Health Benefits, Science and Wisdom, Health and Happiness Books.

5. M Kuman (1997) Modern Aspects of Ancient Acupuncture, Health and Happiness Books.

6. M Kuman (1998) Ancient Wisdom ad Modern Science about Health and Happiness, Health and Happiness Books.

7. M Kuman (1996) What Everybody Needs to Know about Chronic Pain, Chronic Diseases, and Cancer, Health and Happiness Books.

8. M Kuman (1998) Stress as Killer, Stress as Healer, Health and Happiness Books.

9. M Kuman (2018) Chronicle of Medicine and Surgery. 2(1).

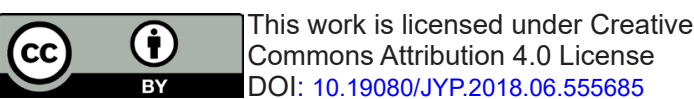

\begin{tabular}{l} 
Your next submission with Juniper Publishers \\
will reach you the below assets \\
- Quality Editorial service \\
- Swift Peer Review \\
- Reprints availability \\
- E-prints Service \\
- Manuscript Podcast for convenient understanding \\
- Global attainment for your research \\
- Manuscript accessibility in different formats \\
( Pdf, E-pub, Full Text, Audio) \\
- Unceasing customer service \\
Track the below URL for one-step submission \\
https://juniperpublishers.com/online-submission.php \\
\hline
\end{tabular}

